\title{
Some myxomycetes from Telangana state, India
}

\author{
C. MANOHARACHARY ${ }^{1}$ and D. NAGARAJU2* \\ ${ }^{1}$ Mycology and Molecular Plant Pathology Laboratory, Department of Botany, Osmania University, Hyderabad 500 007, Telangana, \\ India \\ ${ }^{2}$ Department of Botany, Govt. Degree College, Distt. Warangal, Eturnagaram 506165, Telangana, India
}

Received: 30 May 2017/ Accepted: 20 July 2017/ Published online: 31 August 2017

(C) Indian Phytopathological Society 2017

ABSTRACT: This communication deals with thirty myxomycetous taxa collected and identified from different forests of Telangana state, India. This report is an addition to the previously described taxa from India.

Keywords: Forest, litter, myxomycetes, wood

Myxomycetes are commonly known as slime molds and are classified under phylum myxomycota of Kingdom Protista (Smith, 1998). Around 2000 species are reported from the world, and about 200 species are known from India (Stephenson et al., 1993). Check list of slime molds of India by Ranade et al. (2012) indicates need of systematic surveys of diversified habitats for documentation of myxomycetous taxa. The present investigation adds additional information on myxomycetes collected from diversified habitats of some forest localities of Telangana state. This report form new additions to Telangana state, India.

Samples were collected during June 2015 to December, 2016, from forests of Achampeta, Adilabad, Anantagiri, Bhadrachalam, Hyderabad, Kothagudem, Mahabubnagar, Mannanur, Manchippa, Nalgonda, Narsapur, Nizamabad, Pakala and Yellandu of Telangana state. These samples were collected from different plant parts like dead and decaying leaves, twigs, and leaf

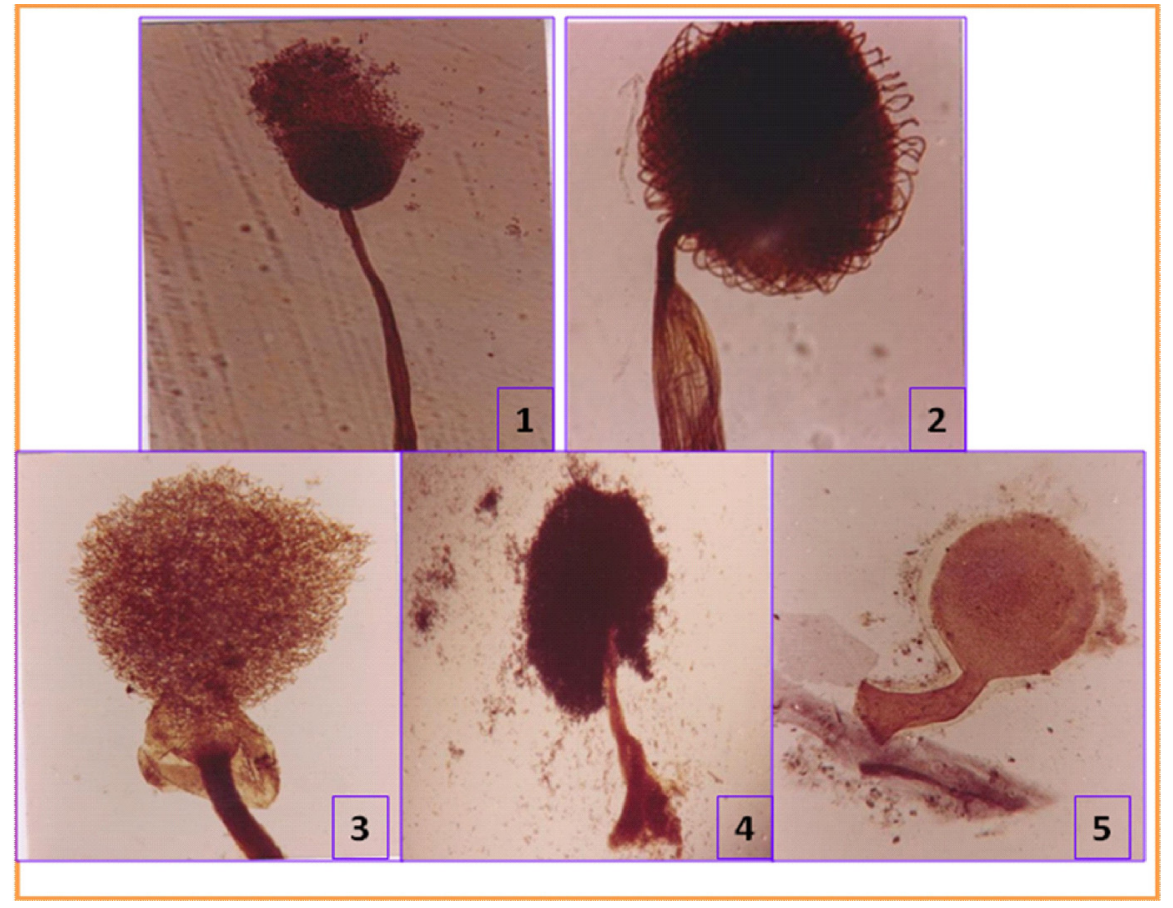

Fig. 1. Cribaria elegans Berk. \& Curt.; 2. Dictydium cancellatum (Batsch) Macbr; 3. Hemitrichia calyculata (Speg.) Farr; 4. Physarum pezizoideum (Jungh.) Pavil \& Lagrade; 5. Trichia botrytis (Pers.) Pers. All Figures were photographed in 100X 
Table 1. List of myxomycetes collected from Telangana state, India

\begin{tabular}{|c|c|c|c|}
\hline Species & Habitat & Place & Accession No. \\
\hline Ceratomyxa fruticulosa (Mull.) Maubr & Wood & Bhadrachalam & OUMH 900 \\
\hline Ceratomyxa hydnoides (Jaco.) D. Kurtz & Bark & Bhadrachalam & OUMH 901 \\
\hline Enteridium lycoperdon (Bull.) M.L. Farr. & Wood & Kothagudem & OUMH 902 \\
\hline Lycogala epidendrum (J.C. Buxb, ex L.) Fr. & Wood & Mannanur & OUMH 903 \\
\hline Cribraria atrofusca G.W. Martin \& love Joy & Fallen leaves & Narsapur & OUMH 904 \\
\hline Cribraria aurantiaca Schrad & Litter & Narsapur & OUMH 905 \\
\hline Cribraria elegans Berk. \& M.A. Curt. & Wood & Narsapur & OUMH 906 \\
\hline Dictydium cancellatum (Batsch) T. Macbr & Wood & Anathagiri & OUMH 907 \\
\hline Arcyria cinerea (Bull.) Pers. & Wood & Nizamabad & OUMH 908 \\
\hline Arcyria glauca Lister ex Minakata & Wood & Nizamabad & OUMH 909 \\
\hline Arcyria incarnata (Pers.) Pers. & wood & Hyderabad & OUMH 910 \\
\hline Arcyra telocarpa (Cooke) Martin \& Alexopoulos & Dead wood & Hyderabad & OUMH 911 \\
\hline Hemitrichia calyculata (Speg.) M.L. Farr. & Dead wood & Hyderabad & OUMH 912 \\
\hline Hemitrichia clavata (Pers.) Rostaf. & Wood & Bhadrachalam & OUMH 913 \\
\hline Trichia botrytis (Pers.) Pers. & Dead wood & Ananthagiri & OUMH 914 \\
\hline Physarum melleum (Berk \& Broome) Massee & Wood & Pakala & OUMH 915 \\
\hline Physarum pezizoideum (Jungh.) Pavill. \& Lagarde & On a fungi & Kothagudem & OUMH 916 \\
\hline Physarella oblonga (Berk. \& M.A. Cart.) Morgan & Dead wood & Kothagudem & OUMH 917 \\
\hline Diachea leucopodia (Bull.) Rost. & Wood & Yellandu & OUMH 918 \\
\hline Diderma effusum (Schwein) Morgan & Bark & Yellandu & OUMH 919 \\
\hline Didymium floccosum Martin, Thind \& Rehill & Dried leaves & Kothagudem & OUMH 920 \\
\hline Comatricha elegans (Racib). G. Lister & Wood & Achampeta & OUMH 921 \\
\hline Comatricha laxa Rost. & Bark & Mahabubnagar & OUMH 922 \\
\hline Comatricha subceesopitosa Peck & Wood & Nalgonda & OUMH 923 \\
\hline Stemonitis axifera (Bull.) T. Macbr. & Wood & Adilabad & OUMH 924 \\
\hline Stemonitis fusca Roth. & Bark & Adilabad & OUMH 925 \\
\hline Stemonitis mussooriensis G.W. Martin, K.S. Thind \& Sohi & Wood & Ananthagiri & OUMH 926 \\
\hline Stemonitis smithii T. Macbr. & Bark & Nizamabad & OUMH 927 \\
\hline Stemonitis uvifera T. Macbr & Wood & Mahabubnagar & OUMH 928 \\
\hline Stemonitis verginiensis Rex. & Dead wood & Mahabubnagar & OUMH 929 \\
\hline
\end{tabular}

Note: OUMH = Osmania University Myxomycetes Herbarium

litter, etc. and carefully transported to the laboratory and preserved in small plastic vials of 2.5 to $4 \mathrm{~cm}$ and were placed in card board boxes. After following the standard procedure samples were dried and treated with potassium chloride for dehydration keeping them in desiccators (Davis, 1965). Hoyer's medium (Distilled water $50 \mathrm{ml}$, Arabic gum $30 \mathrm{~g}$, Chloral hydrate 200g, Glycerin 20g.) was used for observing calcareous members. Non calcareous specimens were observed in glycerin mixed with water (2:1). The examined materials have been deposited and accessioned in Osmania University Myxomycetes Herbarium (OUMH). Identifications were done based on morphotaxonomic criteria and keys provided by Lakhanpal and Mukerji (1981) and Thind (1977).

Myxomycetes are known to colonize diversified habitats from all over the world (Keller, 2012; dela et al., 2014). They are known to occur in temperate, tropical, and sub-tropical forests. However their occurrence is less when compared to soil fungi, litter fungi, mushrooms and wood rotting fungi. Moderate rainfall, a temperature range of $15-28 \pm 2{ }^{\circ} \mathrm{C}$, moderate humidity, good vegetation, altitude and other related factors play important role on the quantitative and qualitative distribution, phenology and dominance of myxomycetes. During present investigation about 300 samples were collected and studied from various forests. About 30 taxa were identified following available literature. Review of literature indicates that Lakhanpal and Mukerji (1981), Thind (1977), Tembhurne and Nanir (2011a,b, 2012), and Ranade et al. (2012) have contributed significantly to the understanding of slime molds from India. Manoharachary et al. (2012) and Manoharachary and Rajithasri (2015) have reported 15 myxomycetes from Telangana and Andhra Pradesh states. Table enlists 30 interesting myxomycetes and their collection details (Table 1 and Fig. 1). This study enriches the data on myxomycete floristics of India. In the present study, wood supported the maximum presence of mixomycetous taxa followed by litter and bark. This is addition to information on myxomycete floristics of Telangana state, India. 


\section{ACKNOWLEDGEMENT}

C. Manoharachary is thankful to NASI, Allahabad for awarding NASI Senior Scientist and Platinum Jubilee fellowship and D. Nagaraju is thankful to Commissioner of Collegiate Education, Telangana, Hyderabad, for encouragement.

\section{REFERENCES}

Davis EE (1965). Preservation of myxomycetes. Mycologia 57: 986-988.

dela Cruz TEE, Rea MAD, Tran HTM, Ko Ko TM and Stephenson SL (2014). A comparative species listing of myxoycetes from tropical (Philippines) and temperture (United State forests). Mycosphere 5: 299-311.

Keller HW (2012). Myxomycete history and taxonomy: highlights from the past, present and future. Based in part on the invited keynote address given at the $7^{\text {th }}$ International Congress on the Systematics and Ecology of Myxomycetes (ICSEM 7), Recife, Brazil. Mycotaxon 122: 369-387.

Lakhanpal TN and Mukherji KG (1981). Indian Myxomycetes. J. Cramer Publishers. pp. 530.

Manoharachary C, Kunwar IK and Tilak KVBR (2012). Some myxomycets from Andhra Pradesh, India. J. Ind. Bot. Soc. 9: 427-429.
Manoharachary C and Rajithasri AB (2015). Interesting slime molds from Telangana state, India. J. Ind. Bot. Soc. 94: 286-288.

Puttoo BL (2010). Seventeen Decades of Mycology and Plant Pathology in Jammu and Kashmir. Indian Phytopath. 63(2): 117-121.

Ranade VD, Korade ST, Jagtap AV and Ranadive KR (2012). Checklist of myxomycetes from India. Mycosphere 3: 358390.

Smith CT (1998). A revised 6 kingdom system of life. Biol. Rev. 73: 203-206.

Stephenson SL, Kalyanasundaram I and Lakhanpal TN (1993). A comparative biogeographical study of myxomycetes in the mid-Appalachians of Eastern North America and two regions of India. J. Biogeogr. 20: 645-657.

Tembhurne RR and Nanir SP (2011a). The myxomycetes of South-West Maharashtra (India)-III. Plant Science Feed 1: 23-27.

Tembhurne RR and Nanir SP (2011b). Five new species of the myomycetes recorded from the south-east region of Maharashtra (India). Science Reporter 1: 65-68.

Tembhurne RR and Nanir SP (2012). New five species of the Myxomycetes recorded from the South-East region of Maharashtra, India. Science Research Reporter 1: 65-68.

Thind KS (1977). The Myxomycetes in India. ICAR, New Delhi, pp. 452. 